\title{
Dissolved and particulate primary production and bacterial production in offshore Antarctic waters during austral summer: coupled or uncoupled?
}

\author{
Xosé Anxelu G. Morán*, Josep M. Gasol, Carlos Pedrós-Alió, Marta Estrada \\ Departament de Biologia Marina i Oceanografia, Institut de Ciències del Mar, CSIC, Pg. Marítim 37-49 \\ 08003 Barcelona, Spain
}

\begin{abstract}
The dependence of heterotrophic bacteria on dissolved organic products released by phytoplankton was estimated in the Weddell and Scotia Seas during austral summer 1998. We used time-course experiments of ${ }^{14} \mathrm{C}$-bicarbonate assimilation and compartmental analysis to estimate primary production of total (TOC), particulate (POC) and dissolved (DOC) organic carbon. Three in situ incubations were also performed in Bransfield Strait. Phytoplanktonic biomass and production were within the ranges previously reported for offshore Antarctic waters, with mean values of $0.45 \mathrm{mg}$ chlorophyll $\mathrm{a} \mathrm{m}^{-3}$ and $0.51 \mathrm{mg} \mathrm{C} \mathrm{m}^{-3} \mathrm{~h}^{-1}$ for total primary production $\left(0.45\right.$ and $0.06 \mathrm{mg} \mathrm{C} \mathrm{m}^{-3}$ $\mathrm{h}^{-1}$ of POC and DOC, respectively). Percent extracellular release (PER $=$ DOC/[POC+DOC]) averaged $13 \%$ (range 5 to $33 \%$ ), a value comparable with those reported for lower latitudes. The production rate of DOC correlated positively with TOC and POC production rates, but not with chlorophyll a concentration, suggesting that availability of recently fixed photosynthate was a key factor regulating phytoplanktonic DOC release. As much as $82 \%$ of the variance in bacterial heterotrophic production (BHP), estimated by ${ }^{3} \mathrm{H}$-leucine incorporation, was accounted for by dissolved primary production. BHP bore no relationship with other phytoplankton-related variables. Assuming a conservative bacterial growth efficiency of $14 \%$, as reported by recent work in Antarctic waters, our experiments indicate that phytoplanktonically produced DOC would suffice to meet bacterial carbon demand. These results suggest a strong coupling between phytoplankton and bacterioplankton through DOC release and uptake under non-bloom conditions in the Southern Ocean.
\end{abstract}

KEY WORDS: Bacteria $\cdot$ Phytoplankton $\cdot$ Bacterial production $\cdot$ DOC $\cdot$ Primary production $\cdot$ Coupling · Southern Ocean

Resale or republication not permitted without written consent of the publisher

\section{INTRODUCTION}

The temporal dynamics of the heterotrophic bacterial processing of dissolved organic matter in the Southern Ocean has been debated extensively during the last few years (see Carlson et al. 1998 and Bird \& Karl 1999 for reviews). The contemporaneous trophic interaction between bacterioplankton and primary produc-

${ }^{*}$ Present address: Instituto Español de Oceanografia, Centro Oceanografico de Xixón, Camin de L'Arbeyal, s/n, 33212 Xixón, Spain. E-mail: xelu.moran@gi.ieo.es ers is mediated by the dissolved organic compounds released by growing phytoplankton cells (Baines \& Pace 1991, Nagata 2000). We will refer to this process as dissolved primary production. Direct bacterial use of algae-produced labile dissolved organic carbon (DOC) (Lancelot 1979, Norrman et al. 1995) has been proposed as an explanation of the generally observed covariation between biomass and activity of phytoplankton and bacterioplankton assemblages (e.g. Cole et al. 1988, White et al. 1991, Gasol \& Duarte 2000). The term 'coupling' is often used, in a rather ambiguous way, to design this covariation. In this work, phyto- 
plankton-bacterioplankton 'coupling' is defined as the dependence of bacteria on DOC supplied by algae. The strength of this phytoplankton-bacterioplankton coupling depends on the degree of limitation of bacteria by carbon versus other limiting factors, and is expected to be highly variable across systems. Whereas in lower-latitude areas algae-derived DOC has been estimated to be $25 \%$ (Lignell 1990, Nagata 2000) or $32 \%$ (Baines \& Pace 1991) of the total labile carbon taken up by bacteria, the comparatively low values of bacterial heterotrophic production (BHP) reported for the Southern Ocean (Bird \& Karl 1999) suggest that DOC released by phytoplankton could amount to a higher percentage of the bacterial carbon demand.

Recent studies have explicitly rejected a marked phytoplankton-bacterioplankton coupling in the Southern Ocean on the basis of the observed time-lags between algal and bacterial peaks of abundance and activity (Billen \& Becquevort 1991, Davidson \& Marchant 1992), or the measured low ratios $(<10 \%)$ of BHP to total primary production (Tupas et al. 1994, Carlson et al. 1998, Bird \& Karl 1999), that have been attributed to a limited supply of labile dissolved organic matter by phytoplankton (Karl 1993). Directly measured rates of phytoplanktonic production of DOC in Antarctic waters have only been presented, as far as we know, by Tilzer \& Dubinsky (1987) and Morán \& Estrada (in press), so the explicit testing of the hypothesis that bacteria are coupled to primary producers is hampered by the scarcity of simultaneous measurements of dissolved primary production and bacterial production. However, the positive correlations between phytoplanktonic and heterotrophic bacterial biomass and production that have been reported (Bird \& Karl 1991, Davidson \& Marchant 1992, Kähler et al. 1997, Lochte et al. 1997) could indirectly support the coupling hypothesis. Evidence of diel cycles of bacterial activity, with peaks coinciding with maximal irradiances, as found in Antarctica (Gasol et al. unpubl. data) and elsewhere (Fuhrman et al. 1985, Gasol et al. 1998) also support the view of a direct link between the bacterial and algal compartments.

These contrasting views may be partially due to the fact that 'coupling' is frequently an ill-defined concept, but could also be related to the 2 types of scenarios that, in a much simplified way, can be found in Antarctic waters during summer. Nearshore waters and iceedge zones often harbour phytoplankton blooms with high biomass and productivity (Fogg 1977, Sullivan et al. 1993), where great amounts of DOC can accumulate seasonally because of bacterial delay in their processing (Davidson \& Marchant 1992). Conversely, offshore waters are generally characterized by low phytoplankton biomass and production (El-Sayed \& Weber 1982, Smith \& Sakshaug 1990, Sakshaug et al.
1991), and are considered to be among the most important HNLC (high nutrient, low chlorophyll) regions of the world ocean. Allochthonous inputs of DOC are negligible in offshore waters, far from the influence of melt-ice DOC. This observation, together with the usually low excess concentrations of bulk DOC in surface waters compared to deep values (e.g. Kähler et al. 1997, Carlson et al. 1998, Doval et al. in press), could lead us to expect a strong phytoplankton-bacterioplankton coupling in offshore areas.

A strong bacterial dependence on dissolved organic compounds of phytoplanktonic origin has also methodological implications concerning the measurement of dissolved primary production with the ${ }^{14} \mathrm{C}$ method, because concurrent bacterial uptake of phytoplanktonic DOC may cause underestimation of its production rate in end-point measurements (Riemann \& Søndergaard 1984). To avoid these potential artifacts, time-course (kinetic) experiments of ${ }^{14} \mathrm{C}$ incorporation into the dissolved and particulate fractions were used (Smith 1982, Smith \& Platt 1984). Partitioning of phytoplanktonic organic carbon production into dissolved and particulate compartments is obviously needed in order to determine whether the Antarctic microbial loop functions differently from that in other pelagic ecosystems, as suggested by Bird \& Karl (1999). Without simultaneous, reliable estimates of the proper variables (in this case dissolved primary production and bacterial production), most arguments about 'coupling or uncoupling' between bacteria and algae will remain speculative.

The objective of the present work was to test whether BHP is correlated with dissolved primary production, in spite of low ratios of BHP to primary production (considered as evidence of uncoupling by some authors [Karl 1993, Carlson et al. 1998, Bird \& Karl 1999]), and whether DOC supply from algae suffices to meet bacterial carbon demand in non-bloom areas, as expected from the above arguments. For this purpose, we chose an area of the Weddell and Scotia Seas away from the influence of coastal or ice-related algal blooms.

\section{MATERIALS AND METHODS}

Study area and water sampling. Data were obtained during the 'E-DOVETAIL' cruise, a Spanish contribution to the joint DOVETAIL (Deep Ocean Ventilation Through Antarctica Intermediate Layers) project, on board the RV 'Hespérides', from 16 January to 17 February 1998. One of the objectives of this cruise was to study the relationships between the distribution of selected biological variables and the physico-chemical gradients existing along transects crossing the southern Antarctic Circumpolar Current between $56^{\circ} \mathrm{S}$ and the ice-edge, which at the time of sampling was 
located at $<61^{\circ} \mathrm{S}$ between 40 and $50^{\circ} \mathrm{W}$, further north than expected from previous years. The locations of the stations are shown in Fig. 1, and the depth and temperature of the sampled water in Table 1.

In addition to the kinetic experiments of ${ }^{14} \mathrm{C}$ incorporation (A experiments), which provided most of the data used in this paper, 3 in situ incubations (B experiments) were performed during daylight hours in the eastern Bransfield Strait, close to the sites of Expts A16 and A17 (Fig. 1). The rest of the experiments were performed in the vicinity of the Weddell-Scotia Confluence, an area of export of Weddell intermediate waters towards the Scotia Sea, characterized by a relatively cold, low-stability water column (Gordon et al. 1977). Except for Stns A1, A5, A6 and A19-A21, the rest were located south of the Scotia Front (unpubl. data). Water for the kinetic experiments was collected mostly from the depth of maximum phytoplanktonic biomass, as shown by the downcast CTD (Neil Brown Mark III) fluorescence profiles, using 121 Niskin bottles attached to a rosette sampler. For the 3 in situ experiments, water was taken before dawn from $5,10,20,30,40,50$, 60 and $80 \mathrm{~m}$ depth.

Chlorophyll a determination. Chlorophyll a ( $\mathrm{chl} a)$ was estimated fluorometrically with a Turner Designs fluorometer. Samples of $100 \mathrm{ml}$ were filtered onto membrane $0.22 \mu \mathrm{m}$ filters (Millipore GSWP) for the estimation of total chl a. In Expts A6 to A21, a parallel $200 \mathrm{ml}$ sample was filtered onto $3 \mu \mathrm{m}$ filters (Millipore SSWP) and then this filtrate was filtered onto $0.22 \mu \mathrm{m}$ filters, for the estimation of the fractions of chl a greater and smaller than $3 \mu \mathrm{m}$. In Expts A1 to A5, fractionation was made with $1.2 \mu \mathrm{m}$ (Millipore RAWP) instead of $3 \mu \mathrm{m}$ filters. All filters were frozen upon collection and pigments were extracted afterwards in acetone $(90 \%)$ for

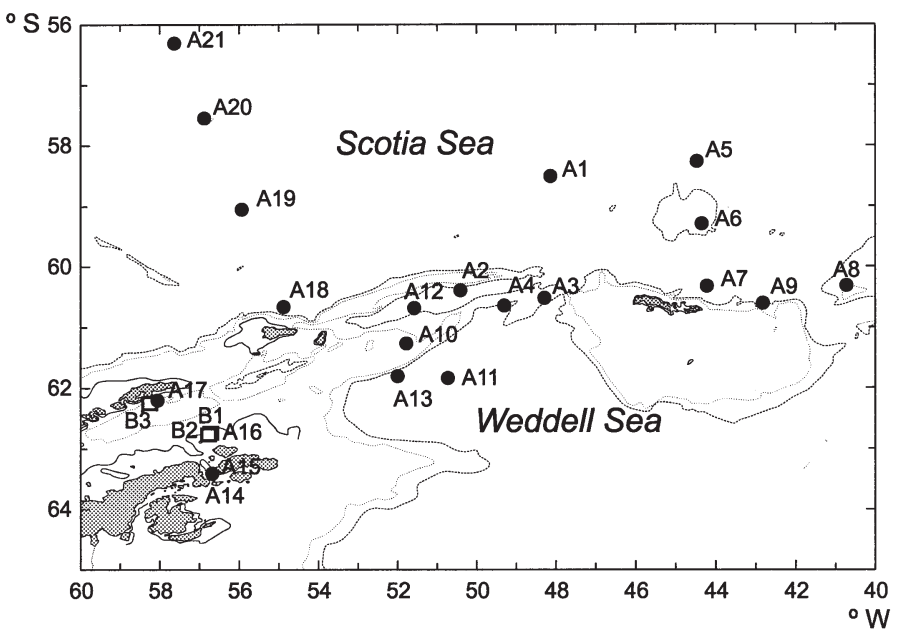

Fig. 1. Map of the Weddell-Scotia Confluence showing stations where time-course (•) and in situ (ㅁ) experiments were carried out. Continuous contour line: $200 \mathrm{~m}$; light dotted contour line: $1000 \mathrm{~m}$; dashed contour line: $2000 \mathrm{~m}$
Table 1. Depth, temperature and chlorophyll a concentration of the water samples used for the time-course experiments of ${ }^{14} \mathrm{C}$ incorporation (Expts A1-A21) and the in situ incubations (Expts B1-B3), surface data. Dates of the experiments are also shown

\begin{tabular}{|lcrcc|}
\hline Expt & Date $(1998)$ & Depth $(\mathrm{m})$ & Temp. $\left({ }^{\circ} \mathrm{C}\right) \mathrm{Chl}$ & a $\left(\mathrm{mg} \mathrm{m}^{-3}\right)$ \\
\hline A1 & 16 Jan & 5 & 1.4 & 0.83 \\
A2 & 19 Jan & 25 & -0.3 & 1.38 \\
A3 & 20 Jan & 62 & -1.6 & 0.46 \\
A4 & 21 Jan & 5 & -0.9 & 0.48 \\
A5 & 23 Jan & 48 & -0.5 & 0.72 \\
A6 & 24 Jan & 56 & -0.4 & 0.42 \\
A7 & 25 Jan & 10 & 0.0 & 0.43 \\
A8 & 26 Jan & 40 & -1.4 & 0.39 \\
A9 & 27 Jan & 60 & -0.9 & 0.23 \\
A10 & 29 Jan & 50 & -0.5 & 0.20 \\
A11 & 30 Jan & 30 & -1.5 & 0.50 \\
A12 & 31 Jan & 30 & -0.2 & 0.49 \\
A13 & 01 Feb & 65 & -0.9 & 0.24 \\
A14 & 04 Feb & 30 & -1.1 & 0.22 \\
A15 & 05 Feb & 5 & -1.0 & 0.23 \\
A16 & 06 Feb & 5 & -0.6 & 0.16 \\
A17 & 10 Feb & 30 & 1.3 & 0.85 \\
A18 & 13 Feb & 10 & 0.8 & 0.39 \\
A19 & 15 Feb & 0 & 3.8 & 0.11 \\
A20 & 16 Feb & 10 & 3.9 & 0.14 \\
A21 & 17 Feb & 24 & 7.2 & 0.54 \\
B1 & 06 Feb & 5 & -0.7 & 0.37 \\
B2 & 07 Feb & 5 & -0.3 & 0.40 \\
B3 & 10 Feb & 5 & 1.8 & 2.12 \\
& & & & \\
\hline
\end{tabular}

$24 \mathrm{~h}$ in the dark at $4^{\circ} \mathrm{C}$ before measurement of the fluorescence.

As an approximation for obtaining phytoplankton biomass (PB), chl a was converted to carbon units by using a C:chl a ratio of $100 \mathrm{mg} \mathrm{C:mg} \mathrm{chl} a$, based on the results obtained by Hewes et al. (1990) in Antarctic low-chl a waters.

Phytoplankton POC and DOC production. Water samples $(70 \mathrm{ml})$ were introduced into transparent (light) and aluminium foil-covered (dark) sterile polystyrene tissue culture bottles (Corning), and spiked with $3.32 \times 10^{5}$ to $4.23 \times 10^{5} \mathrm{~Bq}$ (8.98 to $\left.11.44 \mu \mathrm{Ci}\right)$ of ${ }^{14} \mathrm{C}$-bicarbonate (VKI, Denmark). In the kinetic experiments, samples were incubated under constant light conditions in a controlled-temperature bath at in situ temperature $\left( \pm 0.5^{\circ} \mathrm{C}\right)$. A measured photosynthetically active radiation (PAR) of 45 to $50 \mu \mathrm{mol}$ photons $\mathrm{m}^{-2} \mathrm{~s}^{-1}$ was provided by Philips cool-white fluorescent lamps. This irradiance was similar to saturation values $\left(E_{\mathrm{k}}\right)$ previously reported for Antarctic phytoplankton assemblages in summer (Holm-Hansell \& Mitchell 1991, Figueiras et al. 1994), and was chosen to reflect average daily irradiance of the 0 to $30 \mathrm{~m}$ depth interval of the mixed layer, as samples were obtained from different depths within this layer.

Membrane filters of $0.22 \mu \mathrm{m}$ pore size (the same type used for chl a) were used for separating the particulate and dissolved fractions of primary production (Morán 
et al. 1999). With the filtration technique no distinction is possible between the process of DOC production by phytoplankton and other sources releasing recently fixed photosynthate; therefore we include all of them as dissolved primary production. Four dark bottles (time-zero bottles) were processed immediately at the beginning of the experiment, in the same way as the dark bottles of the subsequent sampling times. In each of the sampling times, 4 light and 4 dark bottles were taken for processing. Aliquots of $5 \mathrm{ml}$ were taken from 2 light and 2 dark bottles and placed in $20 \mathrm{ml}$ scintillation vials for determination of labelled total organic carbon (TOC); the remaining $65 \mathrm{ml}$ were filtered onto $0.22 \mu \mathrm{m}$ membrane filters for determination of total labelled POC (POC $>0.22 \mu \mathrm{m}$ ). Ideally, this fraction would include all photosynthetically produced POC contained in algal biomass plus the bacterial POC resulting from bacterial uptake of DOC released by algae. Aliquots of $5 \mathrm{ml}$ from the remaining 2 light and 2 dark bottles were also filtered through $0.22 \mu \mathrm{m}$ filters and the filtrate collected for determination of labelled DOC. The remaining $65 \mathrm{ml}$ were filtered onto $3 \mu \mathrm{m}$ membrane filters for determination of labelled POC greater than that size (POC $>3 \mu \mathrm{m})$, except in Expts A1 to $\mathrm{A} 5$, where $1.2 \mu \mathrm{m}$ filters were used (POC $>1.2 \mu \mathrm{m})$. This filtration was intended to retain most phytoplanktonic $\mathrm{POC}$, but also to let through most $\mathrm{PO}^{14} \mathrm{C}$ due to heterotrophic bacterial uptake of $\mathrm{DO}^{14} \mathrm{C}$. In order to control for autotrophic production of the fraction smaller than $3 \mu \mathrm{m}(1.2 \mu \mathrm{m}), 4$ additional bottles were filled with pre-filtered water. Two bottles were processed at time zero, and the other 2 were incubated in parallel and filtered at the end of the incubation. Differential pressure was kept below $80 \mathrm{~mm} \mathrm{Hg}$ in all filtrations to prevent cell breakage.

Filters were put into $6 \mathrm{ml}$ scintillation vials, which were left open and fumed with concentrated $\mathrm{HCl}$ (35\%) for a minimum of $12 \mathrm{~h}$ before addition of $4.5 \mathrm{ml}$ of Packard Ultima Gold XR liquid scintillation cocktail. Liquid samples (with labelled TOC or DOC) were acidified with $1 \mathrm{ml} 1 \mathrm{M} \mathrm{HCl}$ and left open under a hood in an orbital shaker for $12 \mathrm{~h}$ before addition of $10 \mathrm{ml}$ scintillation cocktail. Radioactivity was measured on land in a Beckman LS6000LL liquid scintillation counter. The time-zero values were subtracted from subsequent samples for correction of non-photosynthetic incorporation. Dark-bottle values were on average $57 \pm 6 \mathrm{dpm}$ for TOC measurements, $60 \pm 23 \mathrm{dpm}$ for POC $>0.22 \mu \mathrm{m}$, and $65 \pm 10 \mathrm{dpm}$ for DOC, and they did not follow any consistent pattern with time. In spite of the overall low productivity of the experiments, lightbottle values for DOC were on average $15 \%$ higher than dark-bottle values. The radioactivity of the ${ }^{14} \mathrm{C}$ bicarbonate solution added to the incubation bottles of each experiment was determined in $20 \mu \mathrm{l}$ aliquots.
For the 3 in situ experiments, 2 clear and 2 dark bottles per depth (70 $\mathrm{ml}$ each) were inoculated, attached to a free-moving buoy within $1 \mathrm{~h}$ after sample collection, and incubated for $\sim 17 \mathrm{~h}$. This was the approximate length of the day at that time of the year and at that latitude. Samples were processed in the same way as described above, and rates were simply calculated by dividing the difference between incorporation in light and dark bottles by the incubation time. In this case, we will refer to the calculated DOC production as 'apparent DOC' because DOC removal was not accounted for.

Carbon exchange model and compartmental analysis. An example of the kinetics of TOC, POC $>0.22 \mu \mathrm{m}$, POC $>1.2 \mu \mathrm{m}$ and DOC labelling is given in Fig. 2. Two types of 3-compartment carbon-exchange models were used for obtaining steady-state rates of production of POC and DOC in the kinetic experiments, depending on the fraction of POC analyzed (Fig. 3). The model used for total POC (POC $>0.22 \mu \mathrm{m}$ ) is presented in Fig. 3A. The rates of change of carbon content in the compartments are described by the following set of equations:

$$
\begin{aligned}
\frac{\mathrm{d} C_{1}}{\mathrm{~d} t} & =-k(2,1) \times C_{1}+k(1,2) \times C_{2}-k(3,1) \times C_{1} \\
\frac{\mathrm{d} C_{2}}{\mathrm{~d} t} & =k(2,1) \times C_{1}-k(1,2) \times C_{2}+k(2,3) \times C_{3} \\
\frac{\mathrm{d} C_{3}}{\mathrm{~d} t} & =k(3,1) \times C_{1}-k(2,3) \times C_{3}
\end{aligned}
$$

where $C_{i}$ is the carbon concentration in pool $i$ and $k(i, j)$ is the fractional rate constant of flux from $C_{j}$ to $C_{i ;}$ $k(2,1)$ is the constant of POC production and reflects only photosynthetically produced carbon; $k(1,2)$ represents the constant of respiration of synthesized POC, inferred from its influence on $\mathrm{PO}^{14} \mathrm{C}$ kinetics; $k(3,1)$ is the constant of dissolved carbon production. The model assumes implicitly a quasi-instantaneous isotopic equilibrium of the internal phytoplanktonic pool of organic compounds with the external labelled DIC

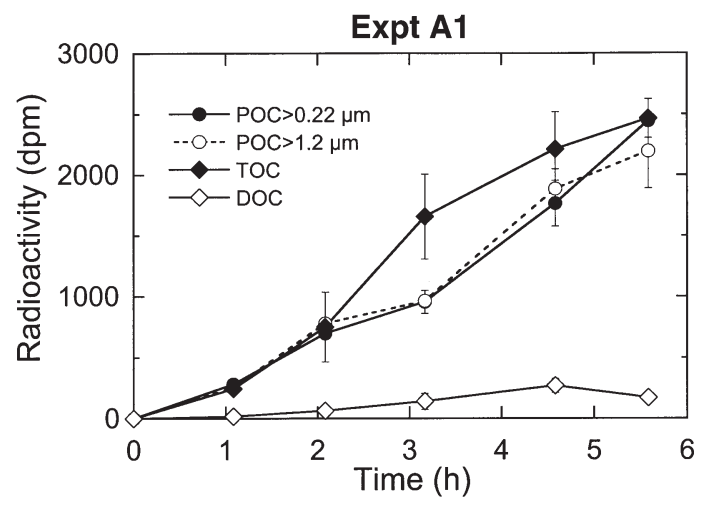

Fig. 2. Time-course of organic carbon labelling in the different fractions measured in Expt A1 (dpm per $70 \mathrm{ml} \mathrm{sample).} \mathrm{Error}$ bars represent standard deviations of duplicates 
A

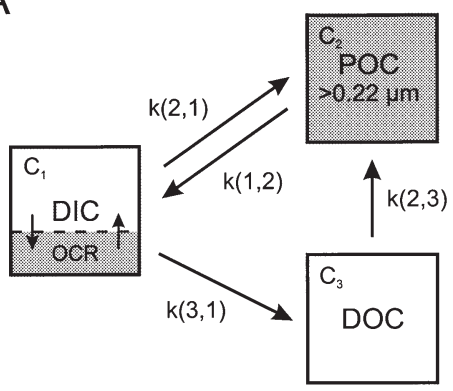

B

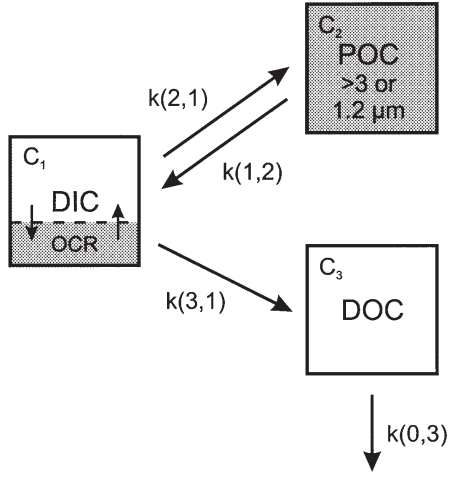

Fig. 3. Carbon-exchange models fitted to experimental data of ${ }^{14} \mathrm{C}$ uptake into different fractions. Compartmental models are detailed in 'Materials and methods'. Shaded boxes represent phytoplankton intracellular pools. OCR: internal pool of organic compounds fated for release

(Smith \& Platt 1984, Morán \& Estrada in press). $k(2,3)$ is the constant of heterotrophic removal of released DOC.

A slightly modified model was used for fitting the POC $>3 \mu \mathrm{m}$ and POC $>1.2 \mu \mathrm{m}$ data (Fig. 3B). Basically, the model was the same except for the rate constant of loss from the DOC pool, representing bacterial uptake in both models. Contrary to the flux represented by $k(2,3)$ in the previous model, in this case the removal of DOC $[k(0,3)]$ did not return to the POC $>3 \mu \mathrm{m}$ pool because, as the fractionation tests showed (see below), only a small percentage of bacteria were retained by the $3 \mu \mathrm{m}$ filters.

The production rates of $\mathrm{POC}>3$ and $>1.2 \mu \mathrm{m}$ were sometimes higher than the corresponding POC $>0.22 \mu \mathrm{m}$ (data not shown). This trend was not significant for POC $>1.2 \mu \mathrm{m}$ versus POC $>0.22 \mu \mathrm{m}$ (paired $t$-test, $\mathrm{p}=0.41, \mathrm{n}=4$ ), but was so for POC $>3 \mu \mathrm{m}$ versus POC $>0.22 \mu \mathrm{m}$ (paired $t$-test, $\mathrm{p}=0.02, \mathrm{n}=15$ ), being $17 \%$ higher on average. In the parallel experiments with pre-filtered water the percentage of total POC production due to small cells was $1.9 \pm 1.0 \%$ (SE) for cells passing through $1.2 \mu \mathrm{m}$ filters and $7.3 \pm 3.1 \%$ for those passing through $3 \mu \mathrm{m}$ filters. The latter percentage was significantly correlated $(r=0.80 ; p=0.002$, $\mathrm{n}=12$ ) with the percentage of chl $a<3 \mu \mathrm{m}$, although values in pre-filtered samples were slightly lower for production than for chl $a$. These results strongly suggest that virtually all primary production was sustained

by phytoplanktonic cells retained by the $3 \mu \mathrm{m}$ filters and that the differences among filters were due to erratic filtration-related artifacts. In view of this we decided to consider all POC fractions $(>0.22,>1.2$ and $>3 \mu \mathrm{m}$ ) to be equivalent. Hereafter, the highest value found will be considered to be the production rate of POC.

TOC production rates based on directly measured labelled TOC were obtained using a 2-compartment model (not shown) comprising only DIC and TOC. The corresponding equations were:

$$
\begin{aligned}
& \frac{\mathrm{d} C_{1}}{\mathrm{~d} t}=-k(2,1) \times C_{1}+k(1,2) \times C_{2} \\
& \frac{\mathrm{d} C_{2}}{\mathrm{~d} t}=k(2,1) \times C_{1}-k(1,2) \times C_{2}
\end{aligned}
$$

where $C_{1}$ represents carbon content in the DIC pool and $C_{2}$ carbon content in the TOC pool. This model accounts for respiration losses of synthesized organic carbon during the incubation time, which are described by the rate constant $k(1,2)$. These results were compared with the sum of POC and DOC production rates calculated in the 3-compartment models described above.

A least-squares non-linear models fitting to actual measurements was performed with SAAM II software for kinetic analyses (SAAM Institute, Inc., Washington DC). Data were weighted by the inverse of the standard deviation of duplicates. The model outputs are the values of the $k(i, j)$ rates $\left(i n \mathrm{~h}^{-1}\right)$. The corresponding POC and DOC production rates $\left(\mathrm{mg} \mathrm{C} \mathrm{m}^{-3} \mathrm{~h}^{-1}\right)$ were calculated from the $k(i, j)$ estimates and a concentration of dissolved inorganic carbon (DIC) of $25000 \mathrm{mg} \mathrm{C} \mathrm{m}^{-3}$, close to the average of DIC values measured in neighbouring Antarctic waters (Álvarez et al. in press). No isotopic discrimination factor was considered for the conversion to carbon units. Percent extracellular release (PER) was calculated as the ratio of DOC production rate to the sum of POC and DOC production rates $\times 100$.

All statistical procedures, except time-course model fitting, were performed with STATISTICA software. Data were log 10-transformed prior to analysis for attaining normality and homogeneity of variances. All linear regressions were calculated according to Model II (Ricker 1973, 1975).

Heterotrophic bacteria: abundance and production. Abundance of heterotrophic bacteria (BN) was determined by flow cytometry according to del Giorgio et al. (1996). Samples of $1.2 \mathrm{ml}$ were taken from the same bottles used for estimating bacterial production and immediately fixed with $1 \%$ paraformaldehyde $+0.05 \%$ glutaraldehyde and stored frozen in liquid $\mathrm{N}_{2}$ until analysis. After the cruise, the samples were thawed, stained with Syto13 (Molecular Probes) at $2.5 \mu \mathrm{M}$ and run through a FACSCalibur (Becton \& Dickinson) flow cytometer 
equipped with a laser emitting at $488 \mathrm{~nm}$. A total of 10000 events were acquired at low flow rate $(\sim 12 \mu \mathrm{l}$ $\min ^{-1}$ ). Fluorescent $0.92 \mu \mathrm{m}$ Polysciences latex beads were added as an internal standard, and their concentration was used to calculate the concentration of picoplanktonic cells in the sample. Bead standard concentration was determined with epifluorescence microscopy. Their signature in plots of side scatter (SSC) versus FL1 (green fluorescence) could identify heterotrophic bacteria. The average fluorescence of bacteria, as normalized to that of the beads (relative FL1), is a rough approximation of bacterial size according to Gasol \& del Giorgio (2000), who provide a relatively good relationship between relative FL1 and size:

Size $\left(\mu \mathrm{m}^{-3}\right)=0.0075+0.11$ relative FL1 $\left(\mathrm{r}^{2}=0.66 ; \mathrm{n}=20\right)$

Bacterial carbon content was in turn calculated using the carbon to volume relationships derived by Norland (1993) from the data of Simon \& Azam (1989):

$$
\operatorname{pgC} \text { cell }^{-1}=0.12 \times\left(\mu \mathrm{m}^{3} \operatorname{cell}^{-1}\right)^{0.7}
$$

and total bacterial biomass $\left(\mathrm{BB}, \mathrm{mg} \mathrm{C} \mathrm{m}^{-3}\right.$ ) was calculated as the product of $\mathrm{BN}$ and bacterial carbon content.

The production rate of heterotrophic bacteria (BHP) was estimated at the beginning and at the end of each ${ }^{14} \mathrm{C}$ uptake experiment with water taken from additional bottles of the same type as those used for primary production and incubated in parallel. In order to test for the possible effect of inhibiting phytoplankton activity, and hence cutting down the supply of labile dissolved substrates, BHP and BN were also determined in water from dark bottles (at the end of the incubation period) and in water previously filtered by 1.2 or $3 \mu \mathrm{m}$ Millipore membrane filters, contained in additional light bottles (both at the beginning and at the end of the incubation). Filtration through $1.2 \mu \mathrm{m}$ (in Expts A1 to A5) or $3 \mu \mathrm{m}$ (A6 to A21) filters was expected to remove autotrophic cells. No prochlorophytes (Prochlorococcus sp.) or cyanobacteria (Synechococcus sp.) were found, in agreement with other reports for the Southern Ocean (e.g. Marchant et al. 1987). Only a few picoeukaryotes were detected by flow cytometry, and their numbers were not quantified.

BHP was estimated with the radioactive $\left({ }^{3} \mathrm{H}\right)$ leucineincorporation method (Kirchman 1993) in $1.2 \mathrm{ml}$ samples incubated in Eppendorf vials (Smith \& Azam 1992). $40 \mathrm{nM}$ leucine was added to 4 vials plus 2 TCA-killed controls. This leucine concentration was found to be saturating in previous concentration-dependent incorporation experiments performed in these waters. The Eppendorf vials were incubated in the dark at temperatures within $\pm 0.5^{\circ} \mathrm{C}$ of the in situ temperatures. Incubations lasted from 2 to $5 \mathrm{~h}$ in accordance with results of linearity experiments carried out during the cruise. Leucine incorporation rates were converted to carbon units by using the theoretical conversion factor of $3.1 \mathrm{kgC} \mathrm{molleu}^{-1}$ (Simon \& Azam 1989), except where otherwise stated. Therefore, the calculated BHP should be regarded as a maximal estimate. The total requirements of organic carbon by heterotrophic bacteria or bacterial carbon demand (BCD) was calculated as $\mathrm{BCD}=\mathrm{BHP} / \mathrm{BGE}$, with a bacterial growth efficiency (BGE) of $14 \%$ (Carlson et al. 1998).

Finally, we measured phytoplankton-bacterioplankton coupling as the statistical correlation between bacterial heterotrophic production and dissolved primary production.

\section{RESULTS}

\section{Chlorophyll a}

Total chl a values were low (Table 1), exceeding $1 \mathrm{mg}$ chl a m $\mathrm{m}^{-3}$ on just 2 occasions (Expts A2 and B3). Mean ( \pm SE) chl a concentration for all experiments was $0.45 \pm$ $0.07 \mathrm{mg} \mathrm{m}^{-3}$, ranging from 0.11 to $2.12 \mathrm{mg} \mathrm{m}^{-3}$. For Expts A1 to A5, the percentage of chl $a$ in the $<1.2 \mu \mathrm{m}$ fraction was $6.2 \pm 1.7 \%$. For the rest of experiments, chl $a$ in the $<3 \mu \mathrm{m}$ fraction amounted to $9.7 \pm 1.4 \%$ of the total. These values were comparable to the $6 \%$ estimate of the fraction of picophytoplanktonic biomass in the Southern Ocean given by Kang \& Lee (1995).

\section{Primary production (kinetic experiments)}

The estimated production rates of total (TOC-pr), particulate (POC-pr) and dissolved organic carbon (DOC-pr) obtained after compartmental model fitting are shown in Table 2. The linear regression between the production rates of $\mathrm{POC}+\mathrm{DOC}$ versus TOC $\left[\log (\mathrm{POC}-\mathrm{pr}+\mathrm{DOC}-\mathrm{pr})=-0.04+0.87 \log\right.$ TOC-pr; $\mathrm{r}^{2}=$ $0.88 ; \mathrm{P}<0.000001 ; \mathrm{n}=18$ ] yielded a slope which was not significantly different from 1 (Model II $95 \%$ confidence limits $=0.73$ to 1.05 ), leading us to conclude that there were no systematic artifacts due to filtration.

Primary productivity ranged from 0.1 to $\sim 2 \mathrm{mg} \mathrm{C} \mathrm{m}^{-3}$ $\mathrm{h}^{-1}$, with mean values of $0.51 \mathrm{mg} \mathrm{C} \mathrm{m}^{-3} \mathrm{~h}^{-1}$ for TOC, 0.45 $\mathrm{mgC} \mathrm{m}^{-3} \mathrm{~h}^{-1}$ for POC and $0.06 \mathrm{mg} \mathrm{C} \mathrm{m}^{-3} \mathrm{~h}^{-1}$ for DOC (Table 2$)$. Mean $( \pm \mathrm{SE})$ productivity indices normalized to $\mathrm{chl}$ a were $1.09 \pm 0.10 \mathrm{mgC}(\mathrm{mg} \mathrm{chl} \mathrm{a})^{-1} \mathrm{~h}^{-1}$ for TOC, $1.00 \pm 0.09 \mathrm{mgC}(\mathrm{mgchl} \mathrm{a})^{-1} \mathrm{~h}^{-1}$ for POC and $0.15 \pm$ $0.03 \mathrm{mgC}(\mathrm{mg} \mathrm{chl} a)^{-1} \mathrm{~h}^{-1}$ for DOC. The rate of dissolved primary production relative to total primary production or percent extracellular release (PER) ranged between 4.6 and $32.5 \%$, with an average of $12.5 \%$ (Table 2 ).

The production rates of TOC and POC were highly correlated to total chl a (Fig. 4A), as described by the following regression equations: 
Table 2. Rates ( $\pm \mathrm{SD}$ of estimates) of phytoplankton TOC, POC and DOC production after fitting the compartmental models detailed in 'Materials and methods'. Percent extracellular release (PER), calculated as DOC-pr/(POC-pr + DOC-pr), is also given. POC-pr is the largest value of all POC fractions measured $(>0.22,>1.2$ or $>3 \mu \mathrm{m})$. - : no data

\begin{tabular}{|lcccr|}
\hline Expt & $\begin{array}{c}\text { TOC-pr } \\
\left(\mathrm{mg} \mathrm{C} \mathrm{m}^{-3} \mathrm{~h}^{-1}\right)\end{array}$ & $\begin{array}{c}\text { POC-pr } \\
\left(\mathrm{mg} \mathrm{C} \mathrm{m}^{-3} \mathrm{~h}^{-1}\right)\end{array}$ & $\begin{array}{c}\text { DOC-pr } \\
\left(\mathrm{mgC} \mathrm{m}^{-3} \mathrm{~h}^{-1}\right)\end{array}$ & $\begin{array}{r}\text { PER } \\
(\%)\end{array}$ \\
\hline $\mathrm{A} 1$ & $0.43 \pm 0.06$ & $0.50 \pm 0.01$ & $0.04 \pm 0.00$ & 6.8 \\
$\mathrm{~A} 2$ & $1.80 \pm 0.11$ & $2.02 \pm 0.12$ & $0.12 \pm 0.06$ & 5.6 \\
$\mathrm{~A} 3$ & $0.36 \pm 0.01$ & $0.27 \pm 0.02$ & $0.04 \pm 0.03$ & 12.0 \\
$\mathrm{~A} 4$ & $0.57 \pm 0.01$ & $0.52 \pm 0.00$ & $0.03 \pm 0.00$ & 4.6 \\
$\mathrm{~A} 5$ & $0.55 \pm 0.13$ & $0.48 \pm 0.07$ & $0.04 \pm 0.07$ & 8.2 \\
$\mathrm{~A} 6$ & $0.26 \pm 0.05$ & $0.26 \pm 0.01$ & $0.02 \pm 0.00$ & 6.9 \\
$\mathrm{~A} 7$ & $0.35 \pm 0.02$ & $0.24 \pm 0.03$ & $0.03 \pm 0.01$ & 12.2 \\
$\mathrm{~A} 8$ & $0.40 \pm 0.02$ & $0.27 \pm 0.01$ & $0.06 \pm 0.02$ & 18.0 \\
$\mathrm{~A} 9$ & $0.23 \pm 0.05$ & $0.18 \pm 0.00$ & $0.01 \pm 0.00$ & 7.2 \\
$\mathrm{~A} 10$ & $0.15 \pm 0.01$ & $0.15 \pm 0.00$ & $0.02 \pm 0.00$ & 13.5 \\
$\mathrm{~A} 11$ & $0.86 \pm 0.01$ & $0.72 \pm 0.03$ & $0.04 \pm 0.01$ & 5.7 \\
$\mathrm{~A} 12$ & $1.19 \pm 0.05$ & $0.84 \pm 0.02$ & $0.12 \pm 0.04$ & 11.8 \\
$\mathrm{~A} 13$ & $0.31 \pm 0.06$ & $0.37 \pm 0.01$ & $0.09 \pm 0.06$ & 19.2 \\
$\mathrm{~A} 14$ & $0.21 \pm 0.01$ & $0.37 \pm 0.01$ & $0.02 \pm 0.00$ & 6.3 \\
$\mathrm{~A} 15$ & $0.24 \pm 0.00$ & $0.35 \pm 0.03$ & - & \\
$\mathrm{A} 16$ & $0.23 \pm 0.01$ & $0.23 \pm 0.01$ & $0.07 \pm 0.03$ & 24.7 \\
$\mathrm{~A} 17$ & $1.37 \pm 0.07$ & $0.66 \pm 0.06$ & $0.21 \pm 0.01$ & 24.2 \\
$\mathrm{~A} 18$ & $0.32 \pm 0.02$ & $0.36 \pm 0.00$ & - & \\
$\mathrm{A} 19$ & $0.11 \pm 0.02$ & $0.07 \pm 0.02$ & - & \\
$\mathrm{A} 20$ & $0.10 \pm 0.01$ & $0.09 \pm 0.00$ & $0.05 \pm 0.00$ & 32.5 \\
$\mathrm{~A} 21$ & $0.67 \pm 0.11$ & $0.49 \pm 0.01$ & $0.03 \pm 0.01$ & 5.5 \\
Mean & 0.51 & 0.45 & 0.06 & 12.5 \\
SE) & $(0.10)$ & $(0.09)$ & $(0.01)$ & $(1.9)$ \\
\hline & & & & \\
\hline
\end{tabular}

$\log$ TOC-pr $=0.10+1.20 \log \mathrm{chl} a\left(\mathrm{r}^{2}=0.78\right.$, $\mathrm{p}<0.001, \mathrm{n}=21$ )

$\log$ POC-pr $=0.04+1.17 \log \mathrm{chl} a\left(\mathrm{r}^{2}=0.72\right.$, $\mathrm{p}<0.001, \mathrm{n}=21$ )

The production rate of DOC was not significantly related to $\mathrm{chl}$ a $(\mathrm{p}=0.15)$ but was significantly correlated to TOC and POC production rates $(\mathrm{r}=0.60$, $\mathrm{p}=0.0084$ for TOC-pr; $\mathrm{r}=0.52, \mathrm{p}=0.027$ for POC-pr; $\mathrm{n}=18$ ). The linear regression between POC and DOC production rates (Fig. 4B) was:

$$
\begin{gathered}
\log \text { DOC-pr }=-0.92+1.00 \log \text { POC-pr }\left(r^{2}=0.27,\right. \\
p=0.027, n=18)
\end{gathered}
$$

\section{Primary production (in situ incubations)}

The chl a concentrations and hourly TOC and POC production rates in the in situ Expts B1 and B2 (Fig. 5A), carried out at the same station as Expt A16 on consecutive days, were within the range found in that experiment. However, Expt B3 showed higher chl a concen-

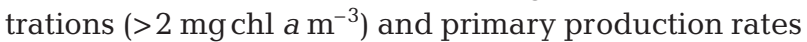
(TOC-pr $>3 \mathrm{mg} \mathrm{C} \mathrm{m}^{-3} \mathrm{~h}^{-1}$ at $10 \mathrm{~m}$ ) than the correspond-
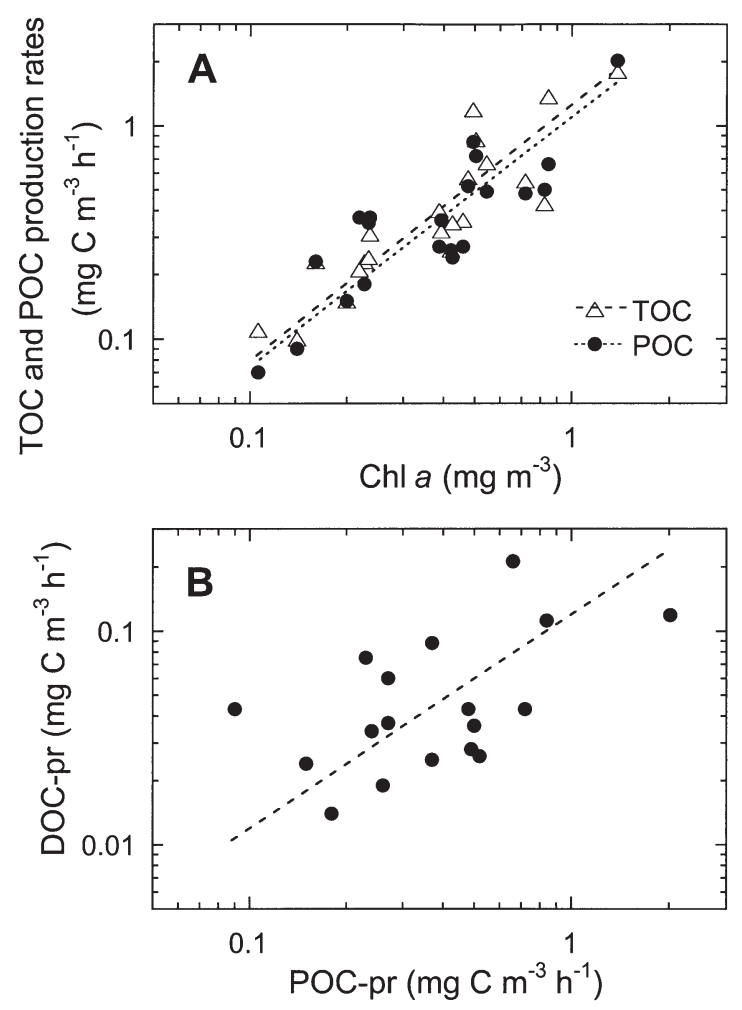

Fig. 4. Relationships between concentration of chlorophyll a and production rates of TOC and POC (A), and between rates of POC and DOC production (B) by phytoplankton in the kinetic experiments

ing kinetic Expt A17 carried out at the same station $12 \mathrm{~h}$ after water sampling for in situ determinations.

Integrated chl a down to $80 \mathrm{~m}$ depth was similar in Expts B1 and B2 (30.2 and $28.1 \mathrm{mg} \mathrm{chl} \mathrm{a} \mathrm{m}^{-2}$, respectively) and reached $123.4 \mathrm{mg} \mathrm{chl} \mathrm{a} \mathrm{m}^{-2}$ in Expt B3. Assuming a C:chl a ratio of 100 (Hewes et al. 1990), the corresponding phytoplankton biomass values in carbon units would be 3023, 2813 and $11527 \mathrm{mg} \mathrm{C} \mathrm{m}^{-2}$, respectively. Daily-integrated values of primary production $\left(\mathrm{PP}_{\text {int }}\right)$, calculated as hourly rates multiplied by 17 (daylight length) varied accordingly. $\mathrm{PP}_{\text {int }}$ values for TOC (and POC) data were 265.7 (223.5) $\mathrm{mg} \mathrm{C} \mathrm{m}^{-2} \mathrm{~d}^{-1}$ in Expt B1, 262.5 (217.7) $\mathrm{mg} \mathrm{C} \mathrm{m}^{-2} \mathrm{~d}^{-1}$ in $\mathrm{B} 2$ and 888.8 (727.8) $\mathrm{mg} \mathrm{C} \mathrm{m}^{-2} \mathrm{~d}^{-1}$ in B3. Apparent water-column-integrated PER, calculated from the difference between $\mathrm{PP}_{\text {int }}$ estimates for TOC and POC, was similar for the 3 experiments: $15.9 \%$ (B1), $17.1 \%$ (B2) and $18.3 \%$ (B3).

\section{Heterotrophic bacteria: abundance and production}

The abundance of heterotrophic bacteria (BN) in the water samples used for the experiments ranged from $1.34 \times 10^{5}$ to $1.07 \times 10^{6}$ cells $\mathrm{ml}^{-1}$, with an average of $5.05 \times 10^{5}$ cells ml ${ }^{-1}$ (Table 3 ), all numbers correspond- 

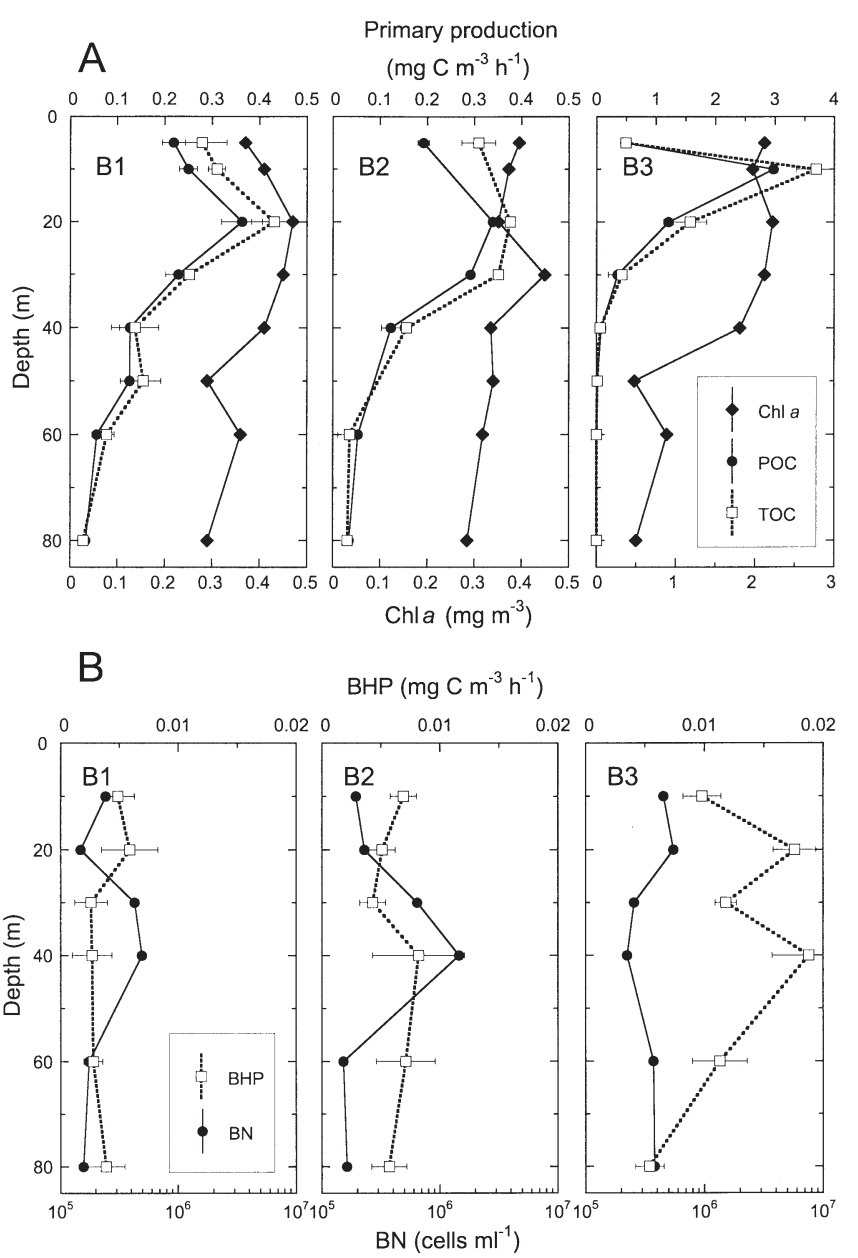

Fig. 5. (A) Vertical distribution of chl a and production rates of TOC and POC at the 3 in situ stations (note different scales for Stn B3); (B) heterotrophic bacterial abundance (BN) and production (BHP) at the same stations (bacterial variables at Stn B2 correspond to CTD cast made $3 \mathrm{~h}$ later at the same position)

ing to light bottles. No BN difference was observed between light and dark bottles after incubation (log-

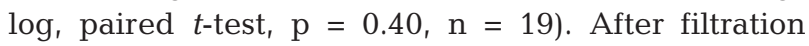
through 1.2 and $3 \mu \mathrm{m}$, an average of $62 \pm 16 \%$ (SD) and $88 \pm 16 \%$, respectively, of total BN passed to the filtrate. Filtration through $0.22 \mu \mathrm{m}$ recovered virtually all heterotrophic bacteria onto the filter, as the average number passing through this filter was $2 \pm 2 \%$ of the whole-water values (Table 3).

Bacterial heterotrophic production (BHP) values of the whole and the pre-filtered water samples, measured both at the beginning and at the end of the corresponding primary production experiments, are shown in Table 4. No significant differences were observed between the values at the beginning and at the end of the experiments, either for the whole (paired $t$-test, $\mathrm{p}=0.41$ ) or pre-filtered (paired $t$-test, $\mathrm{p}=0.55$ ) sam- ples. The BHP values of the incubated light and dark bottles were also not significantly different (paired $t$-test, $\mathrm{p}=0.93$ ), suggesting that, at least during the incubation period, conditions preventing primary production (dark bottles) did not markedly affect bacterial response. The initial whole-sample BHP values were more variable than $\mathrm{BN}$, ranging from 0.77 to $14.25 \mu \mathrm{g} \mathrm{C} \mathrm{m}{ }^{-3} \mathrm{~h}^{-1}$, with an average of $4.79 \mu \mathrm{gC} \mathrm{m} \mathrm{m}^{-3} \mathrm{~h}^{-1}$. Pre-filtration through 1.2 and $3 \mu \mathrm{m}$ filters, and hence the removal of most phytoplanktonic cells, had no apparent effect on bacterial activity (Table 4). Although at low values of BHP (approx. $<0.005 \mathrm{mg} \mathrm{C} \mathrm{m}^{-3} \mathrm{~h}^{-1}$ ) an increase was observed in the BHP of samples pre-filtered through $3 \mu \mathrm{m}$ (Fig. 6), the difference between the estimated BHP in the whole and filtered samples was not significant (paired $t$-test; $\mathrm{p}=0.55, \mathrm{n}=5$ for $1.2 \mu \mathrm{m}$ filters; $\mathrm{p}=0.30$, $\mathrm{n}=15$ for $3 \mu \mathrm{m}$ filters).

Turnover rates of the heterotrophic bacterial compartment, as indicated by the ratio between production and biomass (Table 5) corresponded to mean doubling times longer than $50 \mathrm{~d}$, compared with the $\sim 6 \mathrm{~d}$ for phytoplankton.

In the 3 in situ experiments, $\mathrm{BN}$ ranged from $1.48 \times$ $10^{5}$ to $1.46 \times 10^{6}$ cells $\mathrm{ml}^{-1}$ (Fig. 5B), with maximal abundances at $40 \mathrm{~m}$ in Expts B1 and B2 and a fairly

Table 3. Heterotrophic bacterial abundance measured in whole (unfiltered) light bottles (BN). Also shown are percentages (with respect to $\mathrm{BN}$ ) of bacteria in the dark bottles (D/L) and passing the filters (F/L): $1.2 \mu \mathrm{m}$ (Expts A1-A5), $3 \mu \mathrm{m}$ (Expts A6-A21) and $0.22 \mu \mathrm{m}$ (Expts A1-A21). See 'Materials and methods' for details. -: no data

\begin{tabular}{|c|c|c|c|c|c|}
\hline $\begin{array}{l}\text { Expt } \\
\qquad(10\end{array}$ & $\begin{array}{c}\text { BN } \\
0^{5} \text { cells } \mathrm{ml}^{-1} \text { ) }\end{array}$ & $\begin{array}{l}\mathrm{D} / \mathrm{L} \\
(\%)\end{array}$ & $\begin{array}{c}\mathrm{F} / \mathrm{L} 1.2 \mu \mathrm{m} \\
(\%)\end{array}$ & $\begin{array}{c}\text { F/L } 3 \mu \mathrm{m} \\
(\%)\end{array}$ & $\begin{array}{c}\mathrm{F} / \mathrm{L} \quad 0.22 \mu \mathrm{m} \\
(\%)\end{array}$ \\
\hline A1 & 7.05 & 107.9 & 55.2 & - & 3.9 \\
\hline $\mathrm{A} 2$ & 3.97 & 118.8 & 76.9 & - & 1.6 \\
\hline A3 & 4.39 & 122.5 & 68.1 & - & 1.6 \\
\hline $\mathrm{A} 4$ & 5.22 & 99.8 & 38.6 & - & 0.6 \\
\hline A5 & 9.56 & 100.8 & 73.5 & - & 1.2 \\
\hline A6 & 10.67 & 69.0 & - & 70.6 & 0.3 \\
\hline A7 & 4.36 & 108.1 & - & 82.9 & 1.7 \\
\hline A8 & 1.34 & 114.5 & - & - & 4.1 \\
\hline A9 & 4.71 & 82.9 & - & 83.7 & 1.1 \\
\hline A10 & 5.30 & 104.9 & - & 83.0 & 1.2 \\
\hline A11 & 3.03 & 91.3 & - & 67.7 & 1.4 \\
\hline A12 & 6.44 & 103.9 & - & 85.8 & 1.4 \\
\hline A13 & 1.76 & 118.9 & - & 100.8 & 8.6 \\
\hline A14 & 2.99 & 138.6 & - & 78.7 & 0.9 \\
\hline A15 & 3.60 & 80.7 & - & 127.1 & 2.3 \\
\hline A16 & 2.96 & 106.3 & - & 78.9 & 1.3 \\
\hline A17 & 6.69 & 99.4 & - & 93.7 & 2.8 \\
\hline A18 & 7.02 & 105.9 & - & 88.2 & 1.7 \\
\hline A19 & 4.97 & 111.7 & - & 101.9 & 2.0 \\
\hline A20 & - & - & - & - & - \\
\hline A21 & - & - & - & - & - \\
\hline $\begin{array}{l}\text { Mean } \\
\text { (SD) }\end{array}$ & $\begin{array}{c}5.05 \\
(2.43)\end{array}$ & $\begin{array}{l}104.5 \\
(16.0)\end{array}$ & $\begin{array}{c}62.4 \\
(15.7)\end{array}$ & $\begin{array}{c}87.9 \\
(15.5)\end{array}$ & $\begin{array}{c}2.1 \\
(1.9)\end{array}$ \\
\hline
\end{tabular}


Table 4. Rate of bacterial heterotrophic production $\left(\mu \mathrm{g} \mathrm{C} \mathrm{m}{ }^{-3}\right.$ $\mathrm{h}^{-1}$ ) in the various treatments. $\mathrm{t}=0$ : initial, whole sample; $\mathrm{Lt}=\mathrm{f}$ : final, whole sample; D t = f: final, whole sample, dark bottles; $\mathrm{Ft}=0$ : initial, pre-filtered sample; $\mathrm{Ft}=\mathrm{f}$ : final, pre-filtered sample. -: no data

\begin{tabular}{|c|c|c|c|c|c|}
\hline \multirow{2}{*}{ Expt } & \multicolumn{5}{|c|}{ BHP } \\
\hline & $t=0$ & $L t=f$ & $D t=f$ & $\mathrm{Ft}=0$ & $\mathrm{Ft}=\mathrm{f}$ \\
\hline \multicolumn{6}{|c|}{ Filtered through $1.2 \mu \mathrm{m}$} \\
\hline A1 & 3.6 & 3.0 & 7.9 & 2.0 & 2.8 \\
\hline A2 & 4.3 & 8.5 & 5.8 & 2.4 & 5.1 \\
\hline A3 & 1.7 & 0.6 & 1.7 & 5.2 & 3.2 \\
\hline A4 & 3.0 & 9.4 & 12.6 & 30.6 & 2.9 \\
\hline A5 & 2.2 & 1.8 & 6.8 & 1.5 & 2.3 \\
\hline $\begin{array}{l}\text { Mean A1-A5 } \\
\text { (SE) }\end{array}$ & $\begin{array}{l}3.0 \\
(0.5)\end{array}$ & $\begin{array}{l}4.7 \\
(0.9)\end{array}$ & $\begin{array}{l}7.0 \\
(0.9)\end{array}$ & $\begin{array}{c}8.3 \\
(5.6)\end{array}$ & $\begin{array}{l}3.3 \\
(0.5)\end{array}$ \\
\hline \multicolumn{6}{|c|}{ Filtered through $3 \mu \mathrm{m}$} \\
\hline A6 & 12.2 & 2.9 & 1.2 & 6.0 & 5.3 \\
\hline A7 & 2.2 & 3.5 & 3.8 & 9.4 & 2.6 \\
\hline A8 & 9.4 & 4.5 & 9.0 & - & - \\
\hline A9 & 1.1 & 6.9 & 1.4 & 1.0 & 3.0 \\
\hline A10 & 5.9 & 5.6 & 2.8 & 5.0 & - \\
\hline A11 & 4.5 & 13.5 & 3.1 & 2.5 & 25.9 \\
\hline A12 & 6.9 & 12.8 & 9.1 & 4.6 & 4.6 \\
\hline A13 & 9.7 & 11.5 & 4.7 & 16.1 & 2.8 \\
\hline A14 & 1.2 & 3.1 & 6.2 & 3.0 & 24.9 \\
\hline A15 & 1.2 & 1.6 & 2.3 & 2.1 & 9.9 \\
\hline A16 & 14.3 & 2.1 & 14.5 & 6.6 & 11.0 \\
\hline A17 & 8.8 & 6.4 & 9.2 & 9.7 & 14.1 \\
\hline A18 & 2.2 & 2.9 & 2.1 & 1.7 & 3.0 \\
\hline A19 & 0.8 & 1.8 & 2.0 & 2.8 & 4.7 \\
\hline A20 & 1.9 & 3.0 & 2.5 & 3.6 & 4.7 \\
\hline A21 & 3.5 & 5.5 & 2.6 & 5.7 & 6.3 \\
\hline $\begin{array}{l}\text { Mean A5-A21 } \\
\text { (SE) }\end{array}$ & $\begin{array}{l}5.4 \\
(1.1)\end{array}$ & $\begin{array}{c}5.5 \\
(1.0)\end{array}$ & $\begin{array}{c}4.8 \\
(0.9)\end{array}$ & $\begin{array}{c}5.3 \\
(1.0)\end{array}$ & $\begin{array}{l}8.8 \\
(2.1)\end{array}$ \\
\hline $\begin{array}{l}\text { Mean A1-A21 } \\
\text { (SE) }\end{array}$ & $\begin{array}{c}4.8 \\
(0.9)\end{array}$ & $\begin{array}{l}5.3 \\
(0.8)\end{array}$ & $\begin{array}{c}5.3 \\
(0.8)\end{array}$ & & \\
\hline
\end{tabular}

homogeneous distribution in B3. BHP was below $0.01 \mathrm{mgC} \mathrm{m}^{-3} \mathrm{~h}^{-1}$ throughout the water column in Expts B1 and B2, and reached $\sim 0.02 \mathrm{mgC} \mathrm{m}^{-3} \mathrm{~h}^{-1}$ in Expt B3. Consistently higher BHP values were found in the latter, in accordance with the higher primary production rates also found at this station. Integrated values of bacterial biomass $\left(\mathrm{BB}_{\mathrm{int}}\right)$ were 473,944 and $531 \mathrm{mgC} \mathrm{m}^{-2}$ in Expts B1, B2 and B3, respectively. Daily (hourly rates $\times 24 \mathrm{~h}$ ) integrated BHP values $\left(\mathrm{BHP}_{\text {int }}\right)$ were $7.03,12.72$ and $25.90 \mathrm{mg} \mathrm{C} \mathrm{m}^{-2} \mathrm{~d}^{-1}$.

\section{Relationships between algae and heterotrophic bacteria}

BHP (here considered for the initial whole-sample values, see Table 4) was not correlated with chl a $(p=0.22)$, TOC $(p=0.09)$ or POC $(p=0.15)$ production rates, but it was positively correlated with DOC production rates $(\mathrm{r}=0.51, \mathrm{p}=0.029, \mathrm{n}=18)$. The relationship with DOC-pr also held when the bacterial produc-

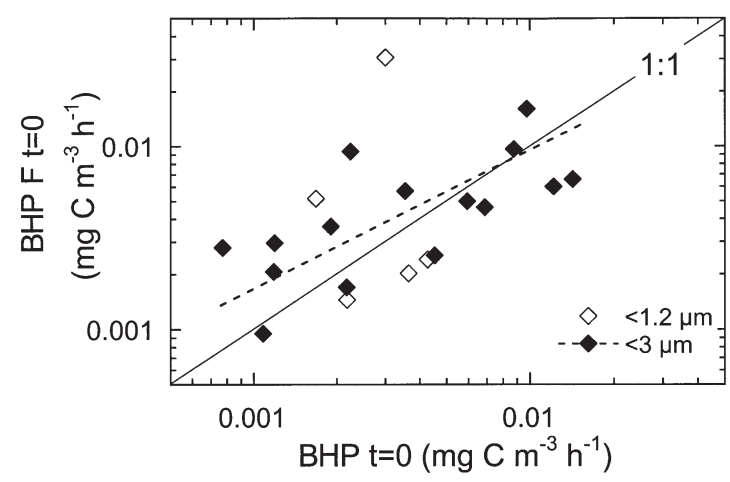

Fig. 6. Relationship between bacterial heterotrophic production in initial, whole samples (BHP $t=0$ ) and in initial, prefiltered samples (BHP F $\mathrm{t}=0$ ). Linear regression between the $<3 \mu \mathrm{m}$ pre-filtered and the whole BHP was: $\log$ BHP $<3 \mu \mathrm{m}$ $=-0.50+0.76 \log \mathrm{BHP} ; \mathrm{r}^{2}=0.48 ; \mathrm{p}=0.004 ; \mathrm{n}=15 ;$ slope was not significantly different from 1 (Model II 95\% confidence limits $=0.50$ to 1.17 )

tion was normalized with respect to bacterial abundance (BHP cell ${ }^{-1} ; \mathrm{r}=0.51, \mathrm{p}=0.043, \mathrm{n}=16$ ). The relationship between BHP and DOC-pr shown in Fig. 7A can be described by the equation:

$$
\begin{aligned}
\log \text { BHP }= & -0.95+1.11 \log \text { DOC-pr } \\
& \left(\mathrm{r}^{2}=0.47, \mathrm{p}=0.002, \mathrm{n}=17\right)
\end{aligned}
$$

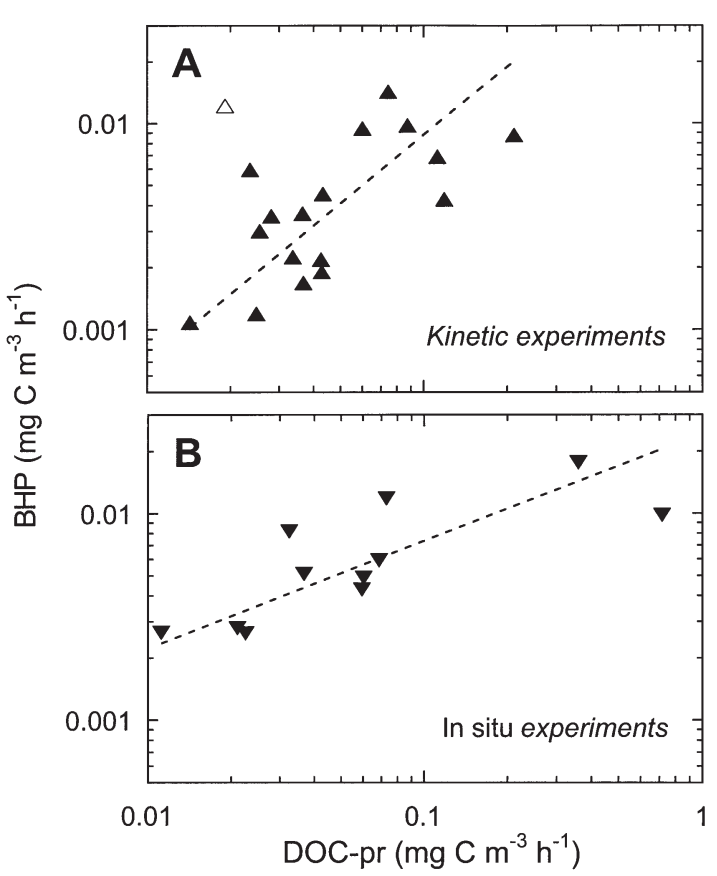

Fig. 7. Relationships between dissolved primary production (DOC-pr) and bacterial heterotrophic production (BHP) for the kinetic experiments of ${ }^{14} \mathrm{C}$ incorporation and the in situ experiments (all depths pooled). Open symbol $(\Delta)$ in $(A)$ was excluded from the linear regression, because its high BHP value was attained only in the initial sample (see Table 4, Expt A6) 

$\mathrm{m}^{-3}$ ) and production $\left(\mathrm{mg} \mathrm{C} \mathrm{m}^{-3} \mathrm{~h}^{-1}\right)$ for kinetic and in situ experiments. For the in situ experiments ratios were calculated from areal integrated values $\left(\mathrm{mgC} \mathrm{m}^{-2}, \mathrm{mgC} \mathrm{m}^{-2} \mathrm{~h}^{-1}\right)$. PB: phytoplankton biomass, calculated with C:chl a ratio of 100 (Hewes et al. 1990); BB: bacterial biomass; TOC-pr: TOC production rate; DOC-pr: DOC production rate; BHP: bacterial heterotrophic production; BCD: bacterial carbon demand calculated with bacterial growth efficiency of $14 \%$ (Carlson et al. 1998); -: no data

\begin{tabular}{|c|c|c|c|c|c|}
\hline Expt 7 & C-pr/PB & BHP/BB & BHP/TOC-pr & BHP/DOC-pr & BCD/DOC-pr \\
\hline A1 & 0.5 & 0.03 & 0.9 & 10.0 & 71 \\
\hline A2 & 1.3 & 0.06 & 0.2 & 3.7 & 26 \\
\hline A3 & 0.8 & 0.02 & 0.5 & 4.6 & 33 \\
\hline A4 & 1.2 & 0.03 & 0.5 & 11.8 & 84 \\
\hline A5 & 0.8 & 0.01 & 0.4 & 5.1 & 37 \\
\hline A6 & 0.6 & 0.07 & 4.7 & 63.5 & 454 \\
\hline A7 & 0.8 & 0.03 & 0.6 & 6.6 & 48 \\
\hline A8 & 1.0 & 0.39 & 2.4 & 15.7 & 112 \\
\hline A9 & 1.0 & 0.01 & 0.5 & 7.5 & 54 \\
\hline A10 & 0.8 & 0.06 & 4.0 & 25.2 & 180 \\
\hline A11 & 1.7 & 0.08 & 0.5 & 11.3 & 81 \\
\hline A12 & 2.4 & 0.06 & 0.6 & 5.8 & 42 \\
\hline A13 & 1.3 & 0.31 & 3.1 & 10.9 & 78 \\
\hline A14 & 1.0 & 0.02 & 0.6 & 4.8 & 34 \\
\hline A15 & 1.0 & 0.02 & 0.5 & - & - \\
\hline A16 & 1.4 & 0.25 & 6.2 & 19.5 & 139 \\
\hline A17 & 1.6 & 0.07 & 0.6 & 4.1 & 30 \\
\hline A18 & 0.8 & 0.02 & 0.7 & - & - \\
\hline A19 & 1.0 & 0.01 & 0.7 & - & - \\
\hline A20 & 0.7 & nd & 1.9 & 4.0 & 29 \\
\hline A21 & 1.2 & nd & 0.5 & 12.6 & 90 \\
\hline Mean & 1.1 & 0.08 & 1.5 & 12.6 & 90 \\
\hline$(\mathrm{SE})$ & 0.1 & 0.03 & 0.4 & 3.3 & 24 \\
\hline B1 & 0.5 & 0.06 & 1.9 & 11.8 & 84 \\
\hline B2 & 0.5 & 0.06 & 3.4 & 20.1 & 144 \\
\hline B3 & 0.5 & 0.20 & 2.1 & 11.3 & 81 \\
\hline Mean & 0.5 & 0.11 & 2.5 & 14.4 & 103 \\
\hline (SE) & 0.0 & 0.05 & 0.5 & 2.9 & 21 \\
\hline
\end{tabular}

Table 5. Ratios (\%) of phytoplankton and bacterioplankton biomass (mg C

on most occasions, as indicated by the BCD/DOC-pr ratio (Table 5).

\section{DISCUSSION}

\section{Dissolved and particulate primary production}

The primary production results presented here correspond to the characteristically low values found in offshore Antarctic waters (El-Sayed \& Weber 1982, Smith \& Sakshaug 1990, Sakshaug et al. 1991), and are in accordance with the low phytoplanktonic biomass found, generally

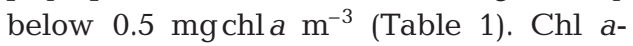
normalized total and particulate primary production rates [mean 1.09 and $1.00 \mathrm{mg} \mathrm{C}$ $(\operatorname{mgchl} a)^{-1} \mathrm{~h}^{-1}$, respectively] were in agreement with previously reported ranges of light-saturated photosynthetic rates in Antarctic waters, including some obtained during bloom events (Jacques 1983, Tilzer et al. 1985, Basterretxea \& Arístegui 1999). As macronutrients (nitrate, phosphate and silicate) are not limiting in the Weddell and Scotia Seas (Kuparinen \& Bjørnsen 1992), low algal biomass and production in offshore waters of these seas may be explained by the limited availability of trace metals such as iron (de Baar et al. 1990) and by light limitation due to relatively deep upper mixed layers (Holm-Hansen \& Mitchell 1991).

Similarly, BHP in the in situ experiments was correlated with the apparent DOC-pr, as described by the regression (Fig. 7B):

$$
\begin{gathered}
\log \mathrm{BHP}=-1.61+0.52 \log \text { DOC-pr }\left(\mathrm{r}^{2}=0.63,\right. \\
\mathrm{p}=0.004, \mathrm{n}=11)
\end{gathered}
$$

but it was not correlated with chl $a$, TOC or POC production rates.

BHP amounted to a small fraction of TOC production rate (Table 5), on average $1.5 \pm 0.4 \%$ (SE) for the kinetic experiments and $2.5 \pm 0.5 \%$ for the in situ experiments. BHP was generally less than $15 \%$ of the phytoplanktonic production rate of DOC. If bacteria were taking up all the DOC actually released by algae and depended only on this source of carbon for growth, the bacterial growth efficiency (BGE) would range between 4 and $64 \%$, with an average value of $13 \%$ for the kinetic experiments. With a BGE of $14 \%$ (Carlson et al. 1998), BCD would be met by DOC production rate
The use of kinetic experiments and subsequent compartmental analysis allows for the correction of heterotrophic uptake of dissolved compounds during incubation. This should produce more reliable estimates of the phytoplanktonic production rate of DOC (Lancelot 1979, Smith 1982) than end-point experiments. In time-course experiments, bacterial uptake of $\mathrm{DO}^{14} \mathrm{C}$ should result in a loss of linearity of its increase versus time. This non-linearity was only apparent in 7 out of 18 experiments; the low value of BHP relative to DOCpr (Table 5) could explain the lack of detection of bacterial uptake in most of the experiments.

The average PER found during this study (13\%) was the same as the average cross-system value reported by Baines \& Pace (1991). Our range of variation for PER ( 5 to $33 \%$ ) compared well with the few values known for the Southern Ocean (Tilzer \& Dubinsky 1987, Morán \& Estrada in press) and with values obtained for other marine environments (see review in Nagata 2000). This 
observation indicates that, outside bloom areas, Antarctic waters represent no special case (compared to more temperate regions) as far as the relative contribution of dissolved primary production is concerned.

More than $70 \%$ of the variance of TOC and POC production rates in the kinetic experiments could be explained by algal biomass as measured by chl a (Fig. 4A). In contrast, the variability in phytoplankton DOC release rates was only significantly explained by the production rates of TOC (Fig. 4B) and POC, and showed no relationship with chl a. Along with previous reports (e.g. Verity 1981, Baines \& Pace 1991), this result suggests that the amount of recently photosynthesized products is a key factor determining the amount that becomes subsequently released extracellularly. Hu \& Smith (1998) reached a similar conclusion with respect to the production of dissolved organic nitrogen (DON) in the Ross Sea. According to Baines \& Pace (1991), if organic compounds were passively released as a consequence of their concentration gradient across the membrane (Bjørnsen 1988), the rate of dissolved primary production should be correlated to a surrogate of the total cellular surface area such as cell size or chl a concentration, which tends to be positively correlated with cell size (Chisholm 1992). Therefore, our results might indirectly support the hypothesis of a transport-mediated system rather than passive diffusion (Bjørnsen 1988) as the principal mechanism of DOM release. The precise mechanisms involved in phytoplanktonic extracellular release, however, remain open, including for example the possible role of protozoan grazers in the appearance of labelled DOC (Bird \& Karl 1999).

\section{Heterotrophic bacteria: abundance and production}

Abundances of heterotrophic bacteria in our samples were similar to other values for the same and adjacent areas (Fuhrman \& Azam 1980, Sullivan et al. 1990, Bird \& Karl 1991, Karl et al. 1991, Vaqué et al. unpubl. data) and varied little in comparison to bacterial activity. The calculation of BHP involves a critical step, which is the choice of an appropriate conversion factor $(\mathrm{CF})$ to convert leucine or thymidine incorporation rates into carbon units. With the widely adopted theoretical CF of $3.1 \mathrm{kgC}$ molleu$^{-1}$ (Simon \& Azam 1989), the BHP estimates obtained (mean $0.005 \mathrm{mgC}$ $\mathrm{m}^{-3} \mathrm{~h}^{-1}$, Table 4) corresponded to the lower end of the range reported for the Antarctic during summer (Tupas et al. 1994, Kähler et al. 1997, Bird \& Karl 1999). Use of an empirical and presumably more

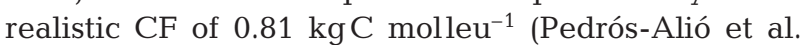
in press) (representing an average of determinations carried out in a previous cruise in the Gerlache and
Bransfield Straits) would have resulted in almost 4 times lower values of BHP. Even with the highest $\mathrm{CF}_{\text {, }}$ BHP comprised a very small fraction of total primary production in this survey, representing generally less than $1 \%$ of the TOC production rate (Table 5), a value close to the ratios reported by Bird \& Karl (1999) for the Gerlache Strait spring bloom. This percentage has been shown to vary during the growth season (Cota et al. 1990), but values below $5 \%$ are not very frequent in different regions and seasons in the Southern Ocean (unpubl. data).

The finding that BHP was similar in light and dark bottles (Table 4) and in pre-filtered and whole unmanipulated samples suggests that at the time-scale of the incubations the likely cut-off in the supply of algal DOC due to darkness or exclusion of algae was not important enough to limit BHP. The lack of clear differences between the whole and pre-filtered samples may be related also to 2 possible effects of filtration, acting in opposite directions. Although pore sizes were designed to let bacteria pass through, some bacterial cells were effectively retained by the filters, leading to a decrease in BHP in the filtered water. Filtration, however, could also enrich the filtrate with dissolved organic matter because of cell breakage, especially under oligotrophic situations (Gasol \& Morán 1999). The latter phenomenon seems to have occurred in the least productive sites, as BHP was higher in the prefiltered than in the whole samples (Fig. 6).

\section{Coupling or uncoupling between phytoplankton and bacterioplankton?}

In the absence of significant allochthonous inputs, the dissolved organic carbon needed for bacterial growth in Antarctic offshore waters should ultimately be derived from the activity of primary producers, regardless of the precise manner in which it is made available: release by actively growing algae, microand mesozooplankton sloppy feeding and excretion, cell lysis, etc. In this paper, phytoplankton-bacterioplankton coupling (i.e. the dependence of bacteria on dissolved compounds supplied by algae) was identified as the existence of a significant relationship between bacterial production and dissolved primary production. We found a positive relationship between the contemporaneous rates of algal DOC and bacterial production in both the kinetic and the in situ experiments, in which DOC-pr was estimated indirectly (Fig. 7). A similar result was found for the comparatively higher productivity waters of Bransfield Strait in a 1995-1996 cruise (Morán \& Estrada in press). When dissolved primary production and leucine incorporation rates from Bransfield Strait were pooled with those 
presented in this paper, applying the same CF for all data (0.81 $\mathrm{kgC} \mathrm{molleu}^{-1}$ : Pedrós-Alió et al. in press), a significant linear regression was obtained (Fig. 8), with DOC-pr explaining as much as $82 \%$ of the variance in BHP. The significantly $<1.0$ regression slope (Model II $95 \%$ confidence limits 0.64 to 0.85 ) suggests a stronger dependence of bacteria on phytoplanktonically released products in the more oligotrophic situations.

Based on the statistical relationship between BHP and DOC-pr (Fig. 8), we hypothesize that phytoplankton and bacterioplankton are tightly coupled through DOC of algal origin in Antarctic low-productivity waters. So far, markedly contrasting views have been held regarding the intensity of phytoplankton-bacterioplankton coupling in the Southern Ocean (Kähler et al. 1997, Bird \& Karl 1999). The contrast may arise, at least in part, because very different biological situations can be met during the growth season in Antarctic waters. As mentioned in the 'Introduction', several studies have demonstrated significant correlations between variables of phytoplanktonic and bacterioplanktonic biomass and activity in the Antarctic (e.g. Fuhrman \& Azam 1980, Cota et al. 1990, Davidson \& Marchant 1992), while others have failed to do so (e.g. Billen \& Becquevort 1991, Bird \& Karl 1991, 1999, Karl et al. 1991, Karl 1993). Overall positive relationships between algal and bacterial variables, using data sets collected across systems, are also common in the literature (e.g. Cole et al. 1988, Baines \& Pace 1991, Gasol \& Duarte 2000), but these relationships do not necessarily hold at the level of individual ecosystems and at particular times. In our experiments, the absence of a significant correlation between BHP and phytoplankton biomass (as measured by chl a) or between BHP and total or particulate primary production could have lead to the erroneous conclusion of lack of coupling. This lack of

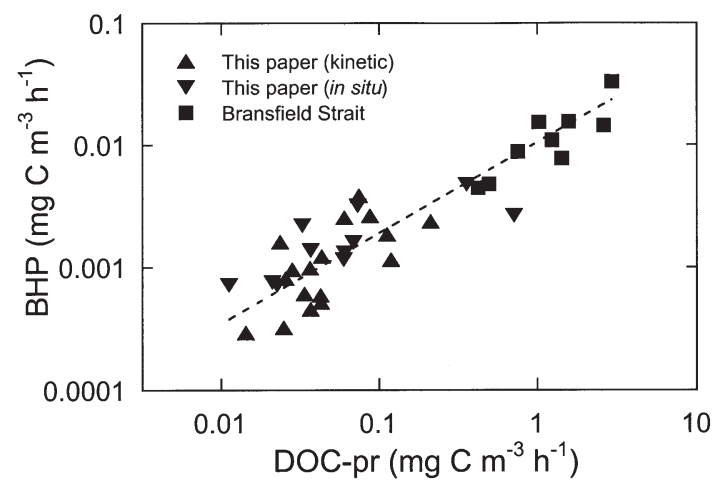

Fig. 8. Relationship between dissolved primary production (DOC-pr) and bacterial heterotrophic production (BHP) in non-bloom waters of the Weddell and Scotia Seas (this paper) and Bransfield Strait (December 1995 to January 1996: FRUELA cruise). Conversion factor of $0.81 \mathrm{~kg} \mathrm{C} \mathrm{molleu}^{-1}$ (PedrósAlió et al. in press) was used for all data. Regression line is $\log \mathrm{BHP}=-1.98+0.74 \log$ DOC-pr; $\mathrm{r}^{2}=0.82, \mathrm{p}<0.001, \mathrm{n}=37$ correlation may rather indicate, as suggested by Pace \& Cole (1996), that little information on the availability of labile organic substrates is provided by either phytoplanktonic standing stock or the rate of production of particulate material. The difficulty of demonstrating a direct link between the phytoplankton and bacterioplankton compartments (Löchte et al. 1997) may thus be largely due to the choice of inappropriate variables. The rate of production of dissolved compounds needs to be considered in order to ascertain the degree of contemporaneous coupling between the 2 planktonic groups.

Whereas in offshore, relatively phytoplankton-poor waters, bacteria seem to depend strongly on DOC released by phytoplankton, Southern Ocean waters harbouring phytoplankton blooms, mostly located in coastal areas (Sullivan et al. 1993), may represent a situation markedly different to that shown here. The seasonal accumulation of dissolved organic matter following Phaeocystis spp.-dominated blooms (Bölter \& Dawson 1982, Davidson \& Marchant 1992, but see Carlson et al. 1998) has been mentioned as evidence for lack of coupling. In our opinion, the observed timelags of about 1 mo between phytoplankton and bacterioplankton peaks of activity (Lancelot et al. 1989, Billen \& Becquevort 1991, Karl et al. 1991, unpubl. data) need not be viewed as evidence of lack of bacterial dependence on phytoplanktonic DOC; a likely explanation is that they arise as a consequence of bacteria being incapable of processing these large inputs of DOC fast enough, perhaps due to micronutrient limitation. After the algal peak, predation on phytoplankton would then release the micronutrients needed for bacterial use of the labile DOC produced during the bloom.

Low BHP/TOC-pr ratios such as those presented in this work (range 0.2 to $6 \%$ : Table 5 ) have also sometimes been regarded as an indication of phytoplankton-bacterioplankton uncoupling in the Southern Ocean (e.g. Tupas et al. 1994, Bird \& Karl 1999). We present evidence that the Antarctic microbial loop need not be as important in terms of carbon processed through it as it is in other systems (Bird \& Karl 1999) for bacteria to be coupled to primary producers. Carlson et al. (1998), who observed comparatively little DOC accumulation after one Phaeocystis spp. bloom, argued that the lack of phytoplanktonic DOC could be the cause for limited bacterial growth, as suggested by Karl (1993) and Bird \& Karl (1999). We cannot exclude that BHP could have increased with supplementary DOC, as reported by Church et al. (2000) for 3 stations located north of the Subantarctic Front (but not at $54^{\circ} \mathrm{S}$, their southernmost station). However, given that our PER values were comparable to those found elsewhere, insufficient phytoplanktonic DOC production 
cannot be readily given as an explanation of the low BHP values, and it certainly did not cause uncoupling between the activities of both groups (Fig. 8). With a conservative BGE value of $14 \%$ (Carlson et al. 1998), roughly half the value (23 to $30 \%$ ) given in another study in the Antarctic by Kähler et al. (1997), our values for phytoplanktonic DOC production would suffice to meet bacterial carbon demand in offshore waters. With the estimated BHP values shown in Table 4, bacteria would on average process $90 \%$ of the DOC actually released by phytoplankton $(103 \%$ in the in situ experiments: Table 5), thus suggesting a fine tuning between release and uptake. On the assumption that other sources of DOC were negligible and heterotrophic bacteria were taking up all the DOC being produced by phytoplankton (i.e. a steady-state system), an average $13 \%$ BGE value would be obtained; this is virtually the same as that found by Carlson et al. (1998), but lower than the median ocean estimate of $22 \%$ (del Giorgio \& Cole 1998). The lack of direct estimates of BGE and leucine CFs for each experiment prevents a definite conclusion, but recently Carlson et al. (1999) provided further evidence of Antarctic BGE estimates higher than $10 \%$. It stems from these results that an accurate knowledge of the leucine conversion factors and the efficiency of bacteria growing on phytoplanktonically released DOC is of critical importance for evaluating the contribution of algae-released products to the total carbon demand of bacterioplankton.

In summary, despite low algal biomass and productivity in offshore Southern Ocean waters, it appears that recently produced algal DOC is sufficient to fuel bacterial growth and metabolism, rendering other potential sources of DOC, such as zooplankton sloppy feeding, unnecessary. The results reported here strongly suggest that Antarctic bacterioplankton and phytoplankton activities are tightly associated through dissolved primary production.

Acknowledgements. We thank all the people on board the RV 'Hespérides' for their help and good humour during the cruise. S. Canut provided very helpful advice. This work was supported by a Spanish CICYT grant (ANT96-0866) to Marc A. García. X.A.G.M. acknowledges the receipt of a FPI predoctoral fellowship from the Spanish Ministry of Education and Culture.

\section{LITERATURE CITED}

Álvarez M, Ríos AF, Rosón G (in press) Spatio-temporal variability of air-sea carbon dioxide and oxygen fluxes in the Bransfield and Gerlache Straits during austral summer 95-96. Deep-Sea Res Part II

Baines SB, Pace ML (1991) The production of dissolved organic matter by phytoplankton and its importance to bacteria: patterns across marine and freshwater systems. Limnol Oceanogr 36:1078-1090
Basterretxea G, Arístegui J (1999) Phytoplankton biomass and production during late austral spring (1991) and summer (1993) in the Bransfield Strait. Polar Biol 21:11-22

Billen G, Becquevort S (1991) Phytoplankton-bacteria relationship in the Antarctic marine ecosystem. Polar Res 10: $245-253$

Bird DF, Karl DM (1991) Spatial patterns of glutamate and thymidine assimilation in Bransfield Strait, Antarctica during and following the austral spring bloom. Deep-Sea Res 38:1057-1075

Bird DF, Karl DM (1999) The uncoupling of bacteria and phytoplankton during the austral spring bloom in Gerlache Strait, Antarctic Peninsula. Aquat Microb Ecol 19: 13-27

Bjørnsen PK (1988) Phytoplankton exudation of organic matter: why do healthy cells do it? Limnol Oceanogr 33:151-154

Bölter M, Dawson R (1982) Heterotrophic utilization of biochemical compounds in Antarctic waters. Neth J Sea Res 16:315-332

Carlson CA, Ducklow HW, Hansell DA, Smith WO Jr (1998) Organic carbon partitioning during spring phytoplankton blooms in the Ross Sea polynya and the Sargasso Sea. Limnol Oceanogr 43:375-386

Carlson CA, Bates NR, Duckow HW, Hansell DA (1999) Estimation of bacterial respiration and growth efficiency in the Ross Sea, Antarctica. Aquat Microb Ecol 19:229-244

Chisholm SW (1992) Phytoplankton size. In: Falkowski PG, Woodhead AD (eds) Primary productivity and biogeochemical cycles in the sea. Plenum Press, New York, p 213-236

Church MJ, Hutchins DA, Ducklow HW (2000) Limitation of bacterial growth by dissolved organic matter and iron in the Southern Ocean. Appl Environ Microbiol 66:455-466

Cole JJ, Findlay S, Pace ML (1988) Bacterial production in fresh and saltwater ecosystems: a cross-system overview. Mar Ecol Prog Ser 43:1-10

Cota GF, Kottmeier ST, Robinson DH, Smith WO, Sullivan CW (1990) Bacterioplankton in the marginal ice zone of the Weddell Sea: biomass, production and metabolic activities during austral autumn. Deep-Sea Res 37: 1145-1167

Davidson AT, Marchant HJ (1992) Prostist abundance and carbon concentration during a Phaeocystis-dominated bloom at an Antarctic coastal site. Polar Biol 12:387-395

de Baar HJW, Buma AGJ, Nolting RF, Cadée GC, Jacques G, Tréguer PJ (1990) On iron limitation of the Southern Ocean: experimental observations in the Weddell and Scotia seas. Mar Ecol Prog Ser 65:105-122

del Giorgio PA, Cole JJ (1998) Bacterial growth efficiency in natural aquatic systems. Annu Rev Ecol Syst 29:503-541

del Giorgio PA, Bird DF, Prairie YT, Planas D (1996) The flow cytometric determination of lake bacterioplankton abundance using the nucleic acid stain SYTO-13. Limnol Oceanogr 41:783-789

Doval MD, Álvarez-Salgado XA, Castro CG, Pérez FF (in press) Dissolved organic carbon distributions in the Bransfield and Gerlache Straits, Antarctica. Deep-Sea Res Part II

El-Sayed SZ, Weber LH (1982) Spatial and temporal variations in phytoplankton biomass and primary production in the Southwest Atlantic and the Scotia Sea. Polar Biol 1: 83-90

Figueiras FG, Pérez FF, Pazos Y, Ríos AF (1994) Light and productivity of Antarctic phytoplankton during austral summer in an ice edge region in the Weddell-Scotia Sea. J Plankton Res 16:233-253

Fogg GE (1977) Aquatic primary production in the Antarctic. Philos Trans R Soc Lond B Biol Sci 279:27-38 
Fuhrman JA, Azam F (1980) Bacterial secondary production estimates for coastal waters of British Columbia, Antarctica, and California. Appl Environ Microbiol 39:1085-1095

Fuhrman JA, Eppley RW, Hagström Å, Azam F (1985) Diel variations in bacterioplankton, phytoplankton, and related parameters in the Southern California Bight. Mar Ecol Prog Ser 27:9-20

Gasol JM, Duarte CM (2000) Comparative analyses and emerging paradigms in aquatic microbial ecology. FEMS Microbiol Ecol 31:99-106

Gasol JM, Giorgio PA (2000) Using flow cytometry for counting natural planktonic bacteria and understanding the structure of planktonic bacterial communities. Sci Mar 64: $197-224$

Gasol JM, Morán XAG (1999) Effects of filtration on bacterial activity and picoplankton community structure as assessed by flow cytometry. Aquat Microb Ecol 16:251-264

Gasol JM, Doval MD, Pinhassi J, Calderón-Paz JI, GuixaBoixereu N, Vaqué D, Pedrós-Alió C (1998) Diel variations in bacterial heterotrophic activity and growth in the northwestern Mediterranean Sea. Mar Ecol Prog Ser 164: 107-124

Gordon AL, Georgi DT, Taylor HW (1977) Antarctic Polar Front Zone in the western Scotia Sea-summer 1975. J Phys Oceanogr 7:309-328

Hewes CD, Sakshaug E, Reid FMH, Holm-Hansen O (1990) Microbial autotrophic and heterotrophic eucaryotes in Antarctic waters: relationships between biomass and chlorophyll, adenosine triphosphate and particulate organic carbon. Mar Ecol Prog Ser 63:27-35

Holm-Hansen O, Mitchell BG (1991) Spatial and temporal distribution of phytoplankton and primary production in the western Bransfield Strait region. Deep-Sea Res 38: 961-980

Hu S, Smith WO Jr (1998) The effects of irradiance on nitrate uptake and dissolved organic nitrogen release by phytoplankton in the Ross Sea. Cont Shelf Res 18:971-990

Jacques G (1983) Some ecophysiological aspects of the antarctic phytoplankton. Polar Biol 2:27-33

Kähler P, Bjørnsen PK, Lochte K, Antia A (1997) Dissolved organic matter and its utilization by bacteria during spring in the Southern Ocean. Deep-Sea Res Part II 44:341-353

Kang SH, Lee SH (1995) Antarctic phytoplankton assemblages in the western Bransfield Strait region, February 1993: composition, biomass, and mesoscale distributions. Mar Ecol Prog Ser 129:253-267

Karl D (1993) Microbial processes in the Southern Ocean. In: Friedman EI (ed) Antarctic microbiology. Wiley-Liss, New York, p 1-63

Karl DM, Holm-Hansen O, Taylor GT, Tien G, Bird DF (1991) Microbial biomass and productivity in the western Bransfield Strait, Antarctica during the 1986-87 austral summer. Deep-Sea Res 38:1029-1055

Kirchman DL (1993) Leucine incorporation as a measure of biomass production by heterotrophic bacteria. In: Kemp PF, Sherr BF, Sherr EB, Cole JJ (eds) Handbook of methods in aquatic microbial ecology. Lewis Publishers, Boca Raton, FL, p 509-512

Kuparinen J, Bjørnsen PK (1992) Bottom-up and top-down controls of the microbial food web in the Southern Ocean: experiments with manipulated microcosms. Polar Biol 12: 189-195

Lancelot C (1979) Gross excretion rates of natural marine phytoplankton and heterotrophic uptake of excreted products in the southern North Sea, as determined by short-term kinetics. Mar Ecol Prog Ser 1:179-186

Lancelot C, Billen G, Mathot S (1989) Ecophysiology of phyto- and bacterioplankton growth in the Southern Ocean Belgian Scientific Research Programme on Antarcticascientific results of phase one (October 1985-January 1989). Plankton Ecol 1:1-97

Lignell R (1990) Excretion of organic carbon by phytoplankton: its relation to algal biomass, primary productivity and bacterial secondary productivity in the Baltic Sea. Mar Ecol Prog Ser 68:85-99

Lochte K, Bjørnsen PK, Giesenhagen H, Weber A (1997) Bacterial standing stock and production and their relation to phytoplankton in the Southern Ocean. Deep-Sea Res Part II 44:321-340

Marchant HJ, Davidson AT, Wright SW (1987) The distribution and abundance of chroococcoid cyanobacteria in the southern Ocean. Proc Nat Inst Polar Res Symp Polar Biol 1: $1-19$

Morán XAG, Estrada M (in press) Phytoplanktonic DOC and POC production in the Bransfield and Gerlache Straits as derived from kinetic experiments of ${ }^{14} \mathrm{C}$ incorporation. Deep-Sea Res Part II

Morán XAG, Gasol JM, Arin L, Estrada M (1999) A comparison between glass fiber and membrane filters for the estimation of phytoplankton POC and DOC production. Mar Ecol Prog Ser 187:31-41

Nagata T (2000) Production mechanisms of dissolved organic matter. In: Kirchman DL (ed) Microbial ecology of the oceans. John Wiley \& Sons, Chichester, p 121-152

Norland S (1993) The relationship between biomass and volume of bacteria. In: Kemp PF, Sherr BF, Sherr EB, Cole JJ (eds) Handbook of methods in aquatic microbial ecology. Lewis Publishers, Boca Raton, FL, p 303-307

Norrman B, Zweifel UL, Hopkinson CS Jr, Fry B (1995) Production and utilization of dissolved organic carbon during an experimental diatom bloom. Limnol Oceanogr 40: 898-907

Pace ML, Cole JJ (1996) Regulation of bacteria by sources and predation tested in whole-lake experiments. Limnol Oceanogr 41:1448-1460

Pedrós-Alió C, Vaqué D, Guixa-Boixereu N, Gasol JM (in press) Bacterioplankton biomass and heterotrophic production in western Bransfield Strait, Bellingshausen Sea and Gerlache Strait, Antarctica during the 1995-1996 austral summer. Deep-Sea Res Part II

Ricker WE (1973) Linear regression in fishery research. J Fish Res Board Can 30:409-434

Ricker WE (1975) A note concerning Professor Jolicoeur's comments. J Fish Res Board Can 32:1494-1498

Riemann B, Søndergaard M (1984) Bacterial growth in relation to phytoplankton primary production and extracellular release of organic carbon. In: Hobbie JE, Williams PJLeB (eds) Heterotrophic activity in the sea. Plenum Press, New York, p 233-248

Sakshaug E, Slagstad D, Holm-Hansen O (1991) Factors controlling the development of phytoplankton blooms in the Antarctic Ocean - a mathematical model. Mar Chem 35: $259-271$

Simon M, Azam F (1989) Protein content and protein synthesis rates of planktonic marine bacteria. Mar Ecol Prog Ser 51:201-213

Smith DC, Azam F (1992) A simple, economical method for measuring bacterial protein synthesis rates in seawater using ${ }^{3} \mathrm{H}$-leucine. Mar Microb Food Webs 6:107-114

Smith REH (1982) The estimation of phytoplankton production and excretion by carbon-14. Mar Biol Lett 3:325-334

Smith REH, Platt T (1984) Carbon exchange and ${ }^{14} \mathrm{C}$ tracer methods in a nitrogen-limited diatom, Thalassiosira pseudonana. Mar Ecol Prog Ser 16:75-87 
Smith WO Jr, Sakshaug E (1990) Polar phytoplankton. In: Smith WO Jr (ed) Polar oceanography. Part B: Chemistry, biology, and geology. Academic Press, San Diego, p 477-526

Sullivan CW, Cota GF, Krempin DW, Smith WO Jr (1990) Distribution and activity of bacterioplankton in the marginal ice zone of the Weddell-Scotia Sea during austral spring. Mar Ecol Prog Ser 63:239-252

Sullivan CW, Arrigo KR, McClain CR, Comiso JC, Firestone J (1993) Distributions of phytoplankton blooms in the Southern Ocean. Science 262:1832-1837

Tilzer MM, Dubinsky Z (1987) Effects of temperature and day length in the mass balance of Antarctic phytoplankton. Polar Biol 7:35-42

Tilzer MM, von Bodungen B, Smetacek V (1985) Light-

Editorial responsibility: Otto Kinne (Editor),

Oldendorf/Luhe, Germany dependence of phytoplankton photosynthesis in the Antarctic Ocean: implications for regulating productivity. In: Siegfried WR, Condy PR, Laws RM (eds) Antarctic nutrient cycles and food webs. Springer-Verlag, Berlin, p 60-69

Tupas LM, Koike I, Karl DM, Holm-Hansen O (1994) Nitrogen metabolism by heterotrophic bacterial assemblages in Antarctic coastal waters. Polar Biol 14:195-204

Verity P (1981) Effects of temperature, irradiance, and daylength on the marine diatom Leptocylindrus danicus Cleve. II. Excretion. J Exp Mar Biol Ecol 55:159-169

White PA, Kalff J, Rasmussen JB, Gasol JM (1991) The effect of temperature and algal biomass on bacterial production and specific growth rate in freshwater and marine habitats. Microb Ecol 21:99-118

Submitted: August 14, 2000; Accepted: February 1, 2001 Proofs received from author(s): October 19, 2001 